\title{
Impact of Companies' Financial Condition and Growth toward Acceptance of Going Concern Audit Opinion: Empirical Study at Company Listed in the Jakarta Islamic Index (JII)
}

\author{
Siti Maria Wardayati ${ }^{1 *}$, Agung Budi Sulistiyo², Rahman El Junusi ${ }^{3}$, Alamsyah ${ }^{4}$ and Labitsta \\ Untsa Afnany ${ }^{5}$ \\ ${ }^{1,2,5}$ Faculty of Economics and Business, University of Jember, Jl.Kalimantan 37, 68121, Jember, Indonesia \\ ${ }^{3}$ Walisongo Islamic Univercsity of Semarang, Indonesia \\ ${ }^{4}$ Faculty of Economics and Business, University of Mataram, Jl.Majapahit 62, 83125, Mataram, Indonesia
}

\begin{abstract}
Objective - This study aims to explain the companies' financial condition and growth which is affecting going concern audit opinion of the companies listed in the Jakarta Islamic Index (JII). Financial condition is examined through the information changes in working capital to total assets, retained earnings to total assets, earnings before interest and taxes to total assets, book value of equity to book value of total liabilities, sales to total assets.

Methodology/Technique - This study applies qualitative research with a description method and the populations used are all companies listed in JII period 2014-2015.

Findings - The results of the study explained that the companies' financial conditions affect going concern audit opinion. The worse the financial condition of the company, the greater the probability of companies to receive going concern audit opinion, and vice versa. An auditor will give a going concern audit opinion on companies that are experiencing financial difficulties. The growth of the companies affects going concern audit opinion. If the sales growth is negative, the continuity of the company will be unstable, because the company will be difficult to make profits. It can cause the financial conditions of the company experience difficulties, so that the company will receive going concern audit opinion.

Novelty - The study contributes literature with its empirical findings in the context of Indonesia.

Type of Paper: Empirical.
\end{abstract}

Keywords: Working Capital to Total Assets; Retained Earnings to Total Assets; Earnings Before Interest and Taxes to Total Assets; Book Value of Equity to Book Value of Total Liabilities; Sales to Total Assets and the Company's Growth. JEL Classification: M41, M42.

\section{Introduction}

Financial Accounting Standards (IAI, 2015) states that one of the basic assumptions of financial statements is going concern of the company. Sejati (2010) explained that financial statement is important because due to differences in interests between users of financial statements and the management as the party who is

\footnotetext{
* Paper Info: Received: January 12, 2017

Accepted: July 8, 2017

* Corresponding author:

E-mail: siti.maria@unej.ac.id

Affiliation: Faculty of Economics and Business, University of Jember, Indonesia.
} 
responsible for the preparation of financial statements. The audit report is used by auditors to express their opinion about the fairness of audited financial statements (Mulyadi, 2002). An audit opinion that contains the company's going concern information is very useful for investors as one of the stakeholders of the audited financial statements (Wardayati, 2004).

Tamba (2009) states many audit failures made by auditors which concern on going concern. The auditor reveals that the company's financial statements have been audited in accordance with the Financial Accounting Standards and there is no material deviation that may affect the decision making. Financial Accounting Standards describe that the companies are assumed not to have the intention or willing to liquidate or materially diminish its business scale (IAI, 2015).

The granting of going concern status by the auditor is conducted with several considerations, such as taking into account the financial condition of the company. The financial condition of the company can be seen from its financial ratios. Praptitorini and Januarti (2007) found evidence that the decision of giving going concern audit opinion prior to the occurrence of bankruptcy was significantly correlated with the probability of bankruptcy and lag variables of audit reports as well as extreme opposite information. PSA No.30 paragraph 1 states that normally, information that is significantly opposed to an entity's survival assumption is related to the inability of the entity to meet its obligations at the due date without selling most of the assets to outsiders through ordinary business, debt restructuring, Imposed from the outside, and other similar activities (IAPI, 2015).

The ratio of company's financial condition used in this research is working capital to total assets, retained earnings to total assets, earnings before interest and tax to total assets, market value of equity to book value of total liabilities, and Sales to total assets. The financial condition of the company is measured by using the prediction model of bankruptcy which is The Revised Altman Model with Z-Score calculation. Fanny and Saputra (2005) revealed that the giving of going concern audit is not influenced by the growth of the auditing company and the reputation of the public accounting firm. Praptitorini and Januarti (2007) showed that the variable of financial condition and the previous year audit opinion significantly influenced the acceptance of going concern opinion.

Setyarno et.al. (2006) concluded that the ratio of liquidity and the previous year audit opinion significantly influenced going-concern audit opinion. Therefore, the problems that arise are: (1) How can be the company's financial condition related to acceptance of going concern audit opinion on companies listed in Jakarta Islamic Index? and (2) How can be growth related to the acceptance of going concern audit opinion on a company registered in the Jakarta Islamic Index ?.

While the purpose of the study is to explain the financial conditions which are related to the acceptance of going concern audit opinion on companies listed in the Jakarta Islamic Index and explain the company's growth and acceptance of going concern audit opinion on companies listed in the Jakarta Islamic Index. Benefits of research is to be an input, especially in terms of evaluation of the audit opinion received by the company on the financial statements it compiled, used as a consideration for the stock to always monitor the financial condition and growth of the company in relation to the acceptance of going concern audit opinion, and as considerations in investing the funds they have in order to achieve the expected rate of return, as well as a reference for further researchers.

\section{Literature Review}

\subsection{Audit Option}

Auditing is the process of collecting and evaluating evidence of measurable information about an economic entity performed by a competent and independent person to determine and report the conformity of information referred to the predefined criteria (Arens et al., 2013) and IAPI (2015) describes the audit opinion is provided by the auditor through several stages of the audit so that the auditor can provide conclusions on the opinion that should be given to the audited financial statements. 


\subsection{Going Concern}

Going Concern is used as an assumption in financial reporting as stated in SA no. 570 paragraph 02 states an entity is deemed to remain in business for a predictable future. Financial statements are prepared on the basis of business continuity unless management intends to liquidate the entity or terminate its operations, or has no realistic alternative other than to take such action. Conditions that could disrupt the business continuity assumption include: negative operating cash flow, major bad financial ratios, clean lancer liabilities positions, substantial operating losses, and management intentions to liquidate its operations.

\subsection{Financial Condition of the Company}

Companies with good financial condition make auditors tend not to issue going-concern audit opinion (Ramadhany, 2004). Carcello and Neal (2000) and Mc Keown et. al. (1991) stated that the more the company's financial condition deteriorates, the greater the company receives the going concern audit opinion from the auditor. Hani and Mukhalsin (2003) and Chen and Cruch (1996) prove that the ratio of profitability and liquidity negatively affect the issuance of going concern audit opinion. The financial condition of the company is measured by using the prediction model of bankruptcy, The Revised Altman Model with Z-Score calculation (Fanny \& Saputra, 2005: 975) with the formula:

$$
Z-\text { Score }=1,2 X 1+1,4 X 2+3,3 X 3+0,6 X 4+1,0 X 5 .
$$

The Z-score value describes the financial condition is divided into several levels or categories listed on Cut off value in Table 1.

Table1. Altman's Cut off Value for Company Go Public

\begin{tabular}{|l|l|}
\hline Cutoff Value & \multicolumn{1}{|c|}{ Description } \\
\hline$Z$-score $>2,99$ & $\begin{array}{l}\text { Indicates the company in a good condition and has no problem } \\
\text { (non-bankrupt company) }\end{array}$ \\
\hline $2,7<Z$-score $<2,99$ & Shows a slight indication of the problem (though not serious). \\
\hline $1,81<Z$-score $<2,7$ & $\begin{array}{l}\text { Indicates that the company is in a prone condition. In this } \\
\text { condition there are many companies with lower scores still } \\
\text { survive. Therefore, the management must be careful in managing } \\
\text { the company's assets in order to avoid bankruptcy. }\end{array}$ \\
\hline Z-score $<1,81$ & $\begin{array}{l}\text { Indicates the company is facing serious bankruptcy threat, this } \\
\text { should be followed up by the company's management in order to } \\
\text { avoid bankruptcy. }\end{array}$ \\
\hline
\end{tabular}

Source: Altman (1968)

Brigham and Weston (2005) describe the ratios relating to financial conditions are: (1) Working Capital to Total Assets calculated by dividing net working capital by total assets, (2) Retained Earnings to Total Assets is a cumulative profitability indicator which is relative to the length of time (3) Earnings Before Interest and Tax to Total Assets showing the company's ability to generate profits from the company's assets, before interest payments and taxes, (4) Market Value of Equity to Book Value of Total Liabilities which indicates a company's ability to meet the obligations of its own equity market value (ordinary shares), and (5) sales to Total Assets which reflects management efficiency in using the overall assets of the company to generate sales and make profit. 


\subsection{Company Growth}

The income statement is the main report to report on the performance of a company during a certain period (IAI, 2015). The negative profit growth of the business activity is one of the negative trends that experience consideration of going concern audit opinion (Santosa \& Wedari, 2007) and Altman (1968) suggest that companies with negative growth indicates greater tendency of bankruptcy so that firms with profits will not go bankrupt. Bankruptcy is one of the foundations for auditors to provide a going concern opinion. Therefore, companies that experience growth negative growth tend to accept going concern opinion. The profit growth of this research is:

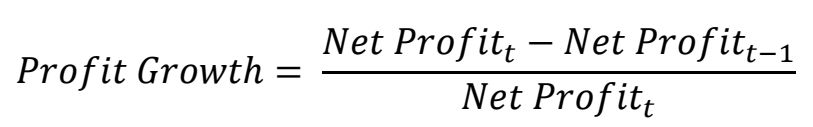

Description: Net profit $=$ Net profit in current year

Net profit $-1=$ Net profit in the previous period

\section{Methodology}

\subsection{Research Design}

This research is a qualitative research with description method by explaining the financial condition such as: Working capital to total assets, retained earnings to total assets, Earnings before interest and taxes to total assets, Book value of equity to book value of total liabilities, Sales to total assets and the company's growth to explain going concern audit opinion.

\subsection{Types and Sources of Data}

The data used are secondary data from Indonesia Stock Exchange concerning with companies registered in Jakarta Islamic Index which get unqualified non-going concern and unqualified going-concern audit opinions. The data are from the audited financial statements of each company listed in the Jakarta Islamic Index published on www.idx.co.id.

\subsection{Population and Samples}

The populations of this study are all companies registered in Jakarta Islamic Index period 20014-2015. The technique of selecting research sample is using purposive sampling method with criteria: (1) Companies which are registered in JII and are not delisting from BEI during period 2014-2015, (2) have been audited and get unqualified going concern and unqualified non going concern opinion.

\subsection{Data Analysis Method}

The technique used is qualitative analysis by using descriptive approach that is examining the problems in the form of current facts from certain population (Indriantoro \& Supomo, 2002). The steps in analyzing the data are: (1) collecting data about companies' profiles, financial reports, and interest rate data; (2) processing the data by: observing and reviewing financial statements in accordance with financial ratios to assess the financial performance of the bank, calculating based on the formula which is set, calculating the research variables where the company's financial condition is measured by using The Revised Altman Model of bankruptcy prediction model, whereas company growth is measured by the ratio of sales growth. The higher the audited companies' sales growth ratio, the less likely it is for an auditor to issue a going concern audit opinion. Going Concern Audit Opinion is measured by dummy variable, where category 1 is for companies that receive going concern audit opinion and category 0 for companies that receive non going concern audit 
opinion

\section{Results}

\subsection{Financial Condition of the Company}

The calculation results of the company's financial condition is presented in Table 2 which shows the result of Z-Score calculation and then compared with the financial condition divided into several levels or categories seen from Cut off value on Altman model.

Table 2. Z-Score Calculation Results of The Revised Altman Model

\begin{tabular}{|c|c|c|c|c|c|c|c|c|c|c|c|c|}
\hline \multirow{2}{*}{$\begin{array}{l}\text { Emitent } \\
\text { code }\end{array}$} & \multicolumn{6}{|c|}{ Year 2014} & \multicolumn{6}{|c|}{ Year 2015} \\
\hline & $\mathbf{X}_{1}$ & $X_{2}$ & $\mathbf{X}_{3}$ & $X_{4}$ & $X_{5}$ & $\begin{array}{c}Z- \\
\text { Score }\end{array}$ & $\mathbf{X}_{1}$ & $\mathbf{X}_{2}$ & $\mathbf{X}_{3}$ & $\mathbf{X}_{4}$ & $X_{5}$ & $\begin{array}{c}Z- \\
\text { Score }\end{array}$ \\
\hline AALI & 0.15 & 0.66 & 0.61 & 0.67 & 1.25 & 4.75 & 0.10 & 0.71 & 033 & 0.69 & 0.98 & 3.60 \\
\hline ANTM & 0.50 & 0.69 & 0.19 & 0.45 & 0.94 & 3.39 & 0.47 & 0.71 & 0.08 & 0.55 & 0.88 & 3.03 \\
\hline ASII & 0.11 & 0.36 & 0.19 & 0.08 & 1.20 & 2.51 & 0.11 & 0.40 & 0.18 & 0.05 & 1.11 & 2.44 \\
\hline BISI & 0.43 & 0.33 & 0.32 & 0.44 & 0.98 & 3.27 & 0.51 & 0.44 & 0.09 & 0.86 & 0.55 & 2.61 \\
\hline BRPT & 0.16 & -0.35 & $\mid-0.26$ & 0.84 & 1.06 & 0.41 & 0.20 & -0.33 & 0.07 & 0.92 & 0.88 & 1.44 \\
\hline BTEL & 0.15 & -0.08 & 0.02 & 0.99 & 0.26 & 0.98 & -0.03 & -0.05 & 0.01 & 0.53 & 0.24 & 0.49 \\
\hline BUMI & 0.05 & 0.24 & 0.19 & 0.44 & 0.64 & 1.94 & -0.01 & 0.13 & 0.07 & 0.24 & 0.43 & 0.98 \\
\hline ELSA & 0.14 & 0.14 & 0.05 & 0.43 & 0.77 & 1.57 & 0.21 & 0.18 & 0.16 & 0.32 & 0.87 & 2.10 \\
\hline $\mathrm{INCO}$ & 0.21 & 0.58 & 0.25 & 0.42 & 0.71 & 2.87 & 0.27 & 0.56 & 0.12 & 0.30 & 0.37 & 2.04 \\
\hline INDY & 0.36 & 0.24 & 014 & 0.15 & 0.27 & 1.57 & 0.30 & 0.20 & 0.08 & 0.08 & 0.21 & 1.16 \\
\hline LSIP & 0.12 & 0.34 & 0.27 & 0.40 & 0.78 & 2.53 & 0.06 & 0.43 & 0.21 & 0.66 & 0.66 & 2.42 \\
\hline PTBA & 0.59 & 0.46 & 0.42 & 0.57 & 1.18 & 4.25 & 0.67 & 0.56 & 0.47 & 050 & 1.11 & 4.53 \\
\hline SGRO & 0.21 & 0.28 & 0.29 & 0.65 & 1.06 & 3.06 & 0.17 & 0.31 & 0.18 & 0.80 & 0.80 & 2.52 \\
\hline SMGR & 0.47 & 0.61 & 0.34 & 0.24 & 1.15 & 3.83 & 0.46 & 0.63 & 0.36 & 0.23 & 1.11 & 3.86 \\
\hline TINS & 0.46 & 0.59 & 0.36 & 0.13 & 156 & 4.22 & 0.44 & 0.63 & 0.11 & 0.18 & 1.59 & 3.47 \\
\hline TLKM & -0.14 & 0.35 & 0.22 & 0.11 & 0.67 & 1.78 & -0.11 & 0.37 & 0.23 & 0.11 & 0.66 & 1.88 \\
\hline TRUB & 0.45 & 0.01 & \begin{tabular}{|l|}
-0.02 \\
\end{tabular} & 0.29 & 0.41 & 1.06 & 0.40 & 0.04 & 0.06 & 0.35 & 0.41 & 1.36 \\
\hline UNSP & 0.05 & 0.12 & 0.06 & 0.17 & 0.62 & 1.15 & 0.00 & 0.15 & 0.07 & 0.16 & 0.46 & 1.00 \\
\hline \begin{tabular}{|l|} 
UNTR \\
\end{tabular} & -0.34 & 0.27 & 0.17 & 0.07 & 1.22 & 1.79 & 0.19 & 0.36 & 0.22 & 0.08 & 1.20 & 2.73 \\
\hline
\end{tabular}

Source: Primary data processed, 2015

where:

X1: Working Capital to Total Assets,

X2: Retained Earnings to Total Assets

X3: Earnings Before Interest and Tax to Total Assets,

X4: Market Value of Equity to Book Value of Total Liabilities,

X5: Sales to Total Assets 


\subsection{Company Growth}

Company growth is measured by the sales growth which is described in Table 3 .

Table 3. Company Growth of Year 2014-2015

\begin{tabular}{|c|c|c|c|c|c|c|}
\hline \multirow{3}{*}{$\begin{array}{c}\text { Emiten } \\
\text { Code }\end{array}$} & \multicolumn{3}{|c|}{2014} & \multicolumn{3}{|c|}{2015} \\
\hline & \multicolumn{2}{|c|}{ In million (IDR) } & \multirow{2}{*}{$\begin{array}{c}\text { Ratio of sales } \\
\text { growth }\end{array}$} & \multicolumn{2}{|c|}{ In million (IDR) } & \multirow{2}{*}{$\begin{array}{c}\text { Ratio of } \\
\text { sales growth }\end{array}$} \\
\hline & Net sales $\mathbf{t}$ & Net sales $t-1$ & & Net sales $\mathbf{t}$ & Net sales $\mathrm{t}-1$ & \\
\hline AALI & $8,161,217$ & $5,960,954$ & 0.37 & $7,424,283$ & $8,161,217$ & $(0.09)$ \\
\hline ANTM & $9,591,961$ & $12,008,202$ & $(0.20)$ & $8,711,370$ & 9,591,961 & (0.09) \\
\hline ASII & $97,064,000$ & $70,183,000$ & 0.38 & $98,526,000$ & $97,064,000$ & 0.02 \\
\hline BISI & $1,627,821$ & 889,588 & 0.83 & 782,125 & $1,627,821$ & $(0.52)$ \\
\hline BRPT & $18,322,898$ & 336,850 & 53.39 & $14,392,940$ & $18,322,898$ & $(0.21)$ \\
\hline BTEL & $2,202,292$ & $1,289,889$ & 0.71 & $2,742,577$ & $2,202,292$ & 0.25 \\
\hline BUMI & $3,378,393$ & $2,265,468$ & 0.49 & $3,219,274$ & $3,378,393$ & $(0.05)$ \\
\hline ELSA & $2,543,913$ & $2,103,690$ & 0.21 & $3,662,331$ & $2,543,913$ & 0.44 \\
\hline INCO & $1,312,097$ & $2,325,858$ & $(0.44)$ & 760,952 & $1,312,097$ & $(0.42)$ \\
\hline INDY & $2,314,449$ & $2,336,962$ & $(0.01)$ & $2,486,580$ & $2,314,449$ & 0.07 \\
\hline LSIP & $3,846,154$ & $2,929,993$ & 0.31 & $3,199,687$ & $3,846,154$ & $(0.17)$ \\
\hline PTBA & $7,216,228$ & $4.123,855$ & 0.75 & $8,947,854$ & $7,216,228$ & 0.24 \\
\hline SGRO & $2,288,143$ & $1.598,931$ & 0.43 & $1,815,557$ & $2,288,143$ & $(0.21)$ \\
\hline SMGR & $12,209,846$ & $9.600,801$ & 0.27 & $14,387,850$ & $12,209,846$ & 0.18 \\
\hline TINS & $9,053,082$ & $8,542,393$ & 0.06 & $7,709,856$ & $9,053,082$ & $(0.15)$ \\
\hline TLKM & $60,689,784$ & $59,440,011$ & 0.02 & $64,596,635$ & $60,689,784$ & 0.06 \\
\hline TRUB & $2,948,680$ & $1,506,202$ & 0.96 & $2,727,511$ & $2,948,680$ & $(0.08)$ \\
\hline UNSP & $2,931,419$ & $1,949,018$ & 0.50 & $2,325,282$ & $2,931,419$ & $(0.21)$ \\
\hline UNTR & $27,903,169$ & $18,165,598$ & 0.54 & $29,241.883$ & $27,903,169$ & 0.05 \\
\hline Mean & $14,505,555$ & $10,924,066$ & 3.14 & $14,613,713$ & $14,505,555$ & $(0.05)$ \\
\hline $\begin{array}{l}\text { Deviation } \\
\text { Standard }\end{array}$ & $23,767,157$ & $19,089,096$ & 11.85 & $24,524,174$ & $23,767,157$ & 0.23 \\
\hline Min. & $1,312,097$ & 336,850 & $(0.44)$ & 760,952 & $1,312,097$ & $(0.52)$ \\
\hline Max. & $97,064,000$ & $70,183,000$ & 53.39 & $98,526,000$ & $97,064,000$ & 0.44 \\
\hline
\end{tabular}

Source: Primary data processed, 2015; IDR - Indonesian Rupiah.

Based on the results of these calculations on each company, the ability of sales growth in the facing competition is quite good because it is able to generate sales. Table 3 shows companies that get going concern audit opinion. 
Table 3. Prediction of Bankruptcy and Audit Opinion of Going Concern

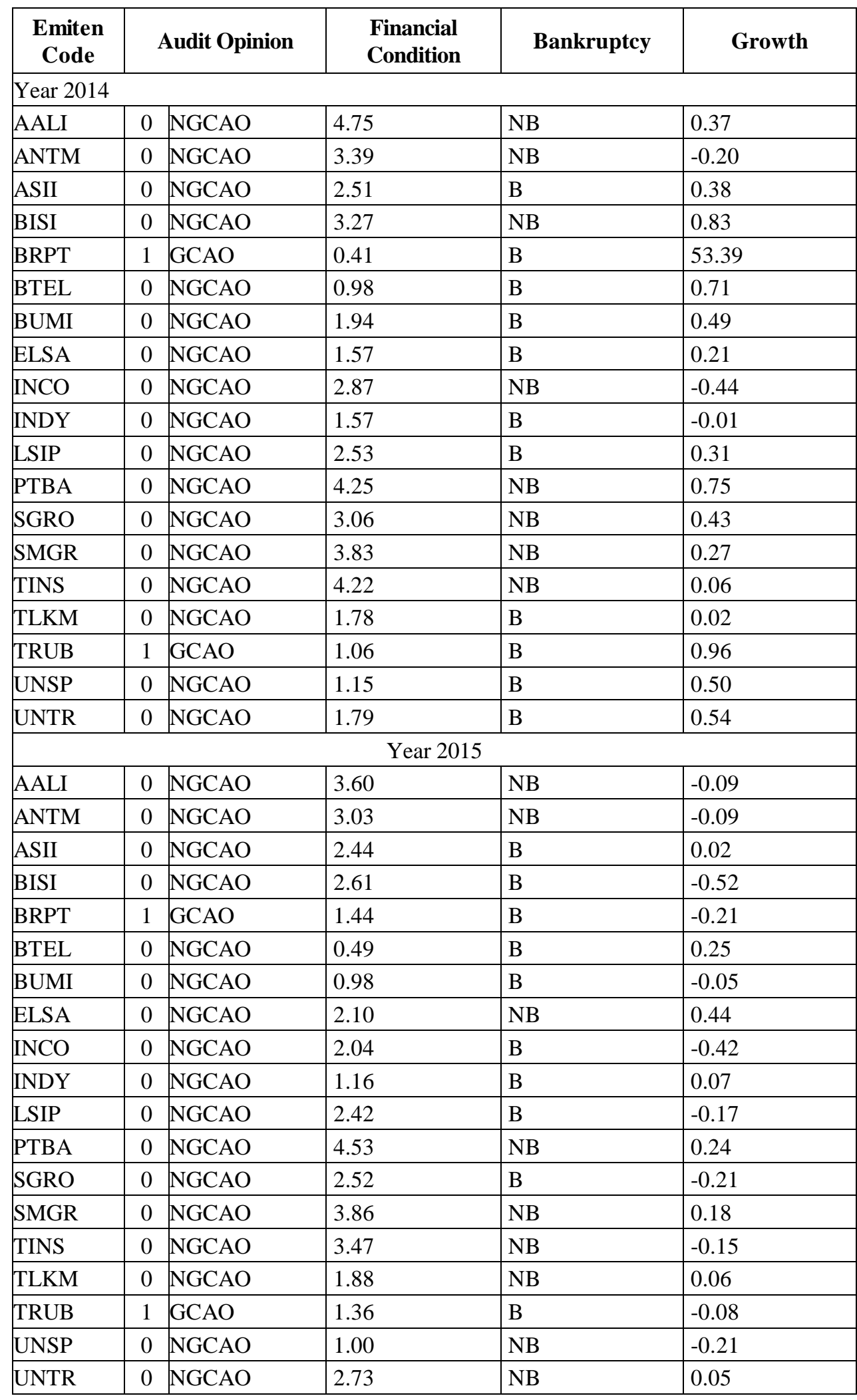

Source: Primary data processed, 2015

where: GCAO (Going Concern Audit Opinion). NGCAO (Non Going Concern Audit Opinion), NB (Not Bankruptcy) dan B (Bankruptcy) 
Table 4. Presents the frequency of company data that gets going concern opinion and which do not get a going concern opinion.

Table 4. Frequency of Going Concern Audit Opinion Recipient

\begin{tabular}{|l|l|r|l|}
\hline No & Description & Number & Percentages \\
\hline 1 & Recipient of going concern audit opinion(GCOA) & 2 & $10.5 \%$ \\
\hline 2 & Recipients of non going concern audit opinion(NGCOA) & 17 & $89.5 \%$ \\
\hline \multicolumn{2}{r|}{ Number of companies } & 19 & $100 \%$ \\
\hline
\end{tabular}

Source: Table 3

\section{Discussion}

\subsection{Financial Condition of the Company}

Issue of going concern audit opinion is very useful for the users of financial statements to make the right decision in investing, because when an investor will invest it is necessary to know the company's financial condition, especially concerning about the survival of the company. According to Chen and Cruch (1996) stated that when the company's economic conditions become uncertain, investors expect the auditor to give an early warning of the company's failure. Altman (1968) and Fanny and Saputra (2005) found that the predicted rate of bankruptcy by using a prediction model reached the level of $82 \%$ accuracy and suggested the use of bankruptcy prediction model as an auditors' tool to decide the company's ability to maintain its survival. The level of company's health can be seen from the company's financial condition. Auditors almost never give going concern audit opinion to companies that do not have financial difficulties. The worse the financial condition of the company the greater the probability of the company to receive going concern opinion.

The financial condition is problematic if the company has negative working capital, negative cash flows, negative operating income, current year losses, and current balance deficit. Companies that receive going concern audit opinion have positive working capital, positive profit and positive retained earnings. Averagely it is bigger than companies with negative working capital, negative profit, and negative retained earnings. While companies that do not accept going concern audit opinion have positive and negative working capitals. Companies that have positive profits have negative retained earnings.

Based on the data, it can be concluded that both companies who receive going-concern audit opinion (GCAO) and those who did not receive the going concern audit opinion (NGCAO) mostly have positive working capital, positive profit, and positive retained earnings. Table 4 shows the grouping of data on the financial condition of the company both that receive going concern audit opinion and that do not receive going concern audit opinion viewed from the variables of Revised Altman bankruptcy model. The variables of Revised Altman are companies that averagely receive going concern audit opinion of $10.5 \%$, this is smaller than companies that do not accept non going concern audit opinion of $89.5 \%$. Therefore, it can be concluded majority of companies during the year 2014-2015 do not accept non-concern audit opinion (NGCAO).

The results of the analysis show that companies that receive going concern audit opinion and non going concern audit opinion are not grouped according to the accepted opinion, this is evidenced by the grouping of companies that receive going concern audit opinion and do not receive going concern audit opinion into one group. The financial condition of the company is said to be bad if the value of proxy measurement of bankruptcy is higher, conversely when the value of proxy is smaller, the financial condition of the company is healthier. Revised Altman bankruptcy model shows that there are two companies that receive going concern audit opinion, so it can be concluded that those two companies are bankrupt companies. It indicates that the financial condition of the company affect the acceptance of going concern audit opinion. If the financial condition is better, then the acceptance of going concern audit opinion is decreased. Auditors almost never give going concern audit opinion to companies that do not have financial difficulties. The worse the financial condition of the company the greater the probability of the company to receive going concern audit opinion. 
The company's financial condition reflects the true level of company's health. The use of Altman Z-score prediction method in the research indicates that there is a significant relationship between the company's financial conditions toward going concern audit opinion. Companies that get going concern audit opinion can minimize financial difficulties by increasing sales, reducing debt on third parties and so forth, so that the companies do not get going concern audit opinion.

The results of the description show that the sales growth in the sample companies has a lot of negative value that affects audit opinion. Basically, company growth is used to measure company's ability in company growth, where the higher sales volume achieved by a company, the higher the ability of company to generate profit, thus it minimizes the chance of auditor to publish going concern audit opinion. The growth value of the company causes the company to be threatened with bankruptcy, so that it will get going concern audit opinion because if the sales growth is negative, the company's continuity also threatened to decrease due to sales that do not develop well. The company can increase the company's growth because sales are the main operations of companies. Sales that continue to increase from year to year will provide opportunities for companies to obtain higher profits. The higher the companies' sales growth ratio, the less likely it is for an auditor to issue a going concern audit opinion.

\section{Conclusion}

The results of the analysis explain that the worse the financial condition of the company the greater the probability of the company to receive going concern audit opinion, and vice versa. An auditor will give going concern audit opinion on companies that experience financial difficulties. The growth of the company can affect going concern audit opinion, if the sales growth is negative, then the company's continuity becomes unstable due to the company will be difficult in obtaining profit. This can lead to financial difficulties so that companies can accept going concern audit opinion.

\section{References}

Altman, E. I. (1968). Financial ratios, discriminant analysis and the prediction of corporate bankruptcy. The journal of finance, 23(4), 589-609.

Arens, A. A., \& Lobbecke, J. K. (2013). Auditing: Pendekatan Terpadu (Judul Asli: Auditing: An Integrated Approach) Edisi Revisi, Jilid 1. Penerjemah Amir Abadi Jusuf. Jakarta: Salemba Empat.

Brigham, E. F., \& Weston, J. F. (2005). Dasar-Dasar Manajemen Keuangan [Fundamentals of Financial Management]. Nineth Edition. Volume 2. Jakarta: Erlangga.

Carcello, J. V., \& Neal, T. L. (2000). Audit committee composition and auditor reporting. The Accounting Review, 75(4), 453-467.

Chen, K. C., \& Church, B. K. (1996). Going concern opinions and the market's reaction to bankruptcy filings. Accounting Review, 71, 117-128.

Fanny, M., \& Saputra, S. (2005). Opini Audit Going Concern: Kajian Berdasarkan Model Prediksi Kebangkrutan, Pertumbuhan Perusahaan, dan Reputasi Kantor Akuntan Publik (Studi pada Emiten Bursa Efek Jakarta) [Audit Opinion Going Concern: Review Based on Prediction Model of Bankruptcy, Corporate Growth, and Public Accountant Reputation (Study on Issuers of Jakarta Stock Exchange)]. Simposium Nasional Akuntansi VII. Solo.

Hani, C., \& Mukhlasin. (2003). Going Concern Dan Opini Audit (Studi Pada Perusahaan Perbankan di BEJ). Simposium Nasional Akuntansi VI. Surabaya.

Indonesia, I. A. (2015). Standar Akuntansi Keuangan [Financial Accounting Standards]. Jakarta: Salemba Empat.

Indriantoro, N., \& Supomo, B. (2002). Metodologi Penelitian Bisnis Untuk Akuntansi \& Manajemen [Business Research Methodology for Accounting \& Management]. First Edition. Yogyakarta: BPFE.

McKeown, J. C., Mutchler, J. F., \& Hopwood, W. (1991). Towards an explanation of auditor failure to modify the audit opinions of bankrupt companies. Auditing-a Journal of Practice \& Theory, 10, 1-13.

Mulyadi, K. P. (2002). Auditing. Penerbit Salemba Empat. Jakarta.

Praptitorini, M.D. \& Januarti, I. (2007). Analisis Pengaruh Kualitas Audit, Debt Default, dan Opinion Shopping terhadap Penerimaan Opini Going Concern. Makalah Disampaikan dalam Simposium Nasional Akuntansi X. Makassar: 26-28 Juli. 
Publik, I. A. I. K. A. (2015). Standar Profesional Akuntan Publik. Jakarta: Salemba Empat.

Ramadhany, A. (2004). Analisis Faktor-Faktor yang Mempengaruhi Penerimaan Going Concern pada Perusahaan Manufaktur yang Mengalami Financial Distress di Bursa Efek Jakarta [Analysis of Factors Affecting the Acceptance of Going Concern on Manufacturing Companies Experiencing Financial Distress on the Jakarta Stock Exchange]. Jurnal Maksi, 4.

Santosa \& Wedari. (2007). Analisis Faktor-faktor yang Mempengaruhi Kecenderungan penerimaan Opini Audit Going Concern [Analysis of Factors Affecting the Tendency of Going Concern Audit Opinion]. JAAI, 11(2), 141-158.

Sejati, G.P. (2010). Analisis Faktor Akuntansi Dan Non Akuntansi Dalam Memprediksi Peringkat Obligasi Perusahaan Manufaktur. Bisnis \& Birokrasi [Accounting And Non-Accounting Factors Analysis In Predicting Bonds of Manufacturers. Business \& Bureaucracy], Jurnal Ilmu Administrasi dan Organisasi. 17(1):70-78.

Setyarno, E. B., Januarti, I., \& Faisal. (2006). Pengaruh Kualitas Audit, Kondisi Keuangan Perusahaan, Opini Audit. Tahun Sebelumnya, Pertumbuhan Perusahaan Terhadap Opini Audit Going Concern [Effect of Audit Quality, Company Financial Condition, Audit Opinion. Previous Year, Corporate Growth Against Going Concern Audit Opinion]. Simposium Nasional Akuntansi IX. Padang.

Tamba, R. U. B. (2009). Pengaruh Debt Default, Kualitas Audit, dan Opini Audit Terhadap Opini Going Concern Pada Perusahaan Manufaktur yang Terdaftar Di Bursa Efek Indonesia [Effect of Debt Default, Audit Quality, and Audit Opinion Against Going Concern Opinion At Manufacturing Company Listed In Indonesia Stock Exchange]. Fakultas Ekonomi Universitas Sumatera Utara.

Wardayati, S. M., (2004). Auditing Suatu Pengenalan [Auditing An Introduction]. Jember: Tapal Kuda.

www.idx.co.id 